\title{
Preparation and characterization of $\mathrm{Li}_{4} \mathrm{Ti}_{5} \mathrm{O}_{12}$ synthesized using hydrogen titanate nanowire for hybrid super capacitor
}

\author{
Jong Hyun KIM, Jung Rag YOON* \\ R\&D Center, Samwha Capacitor Co., Ltd., Yongin, Gyeonggi 449-884, R.O. Korea \\ Received: May 06, 2013; Revised: June 25, 2013; Accepted: July 03, 2013 \\ CThe Author(s) 2013. This article is published with open access at Springerlink.com
}

\begin{abstract}
The electrical characteristics of hybrid super capacitor were evaluated by synthesizing LTO $\left(\mathrm{Li}_{4} \mathrm{Ti}_{5} \mathrm{O}_{12}\right)$ using $\mathrm{TiO}_{2}$ having a hydrogen titanate nanowire form. Preparation of the hydrogen titanate nanowire was implemented by using $\mathrm{TiO}_{2}$ having size of $60 \mathrm{~nm}$ and $\mathrm{NaOH}$, and performing synthesis at $70{ }^{\circ} \mathrm{C}$ for $6 \mathrm{~h}$ with a sonochemical method. LTO compound was synthesized at $150{ }^{\circ} \mathrm{C}$ for $36 \mathrm{~h}$ and at $180{ }^{\circ} \mathrm{C}$ for $36 \mathrm{~h}$ respectively by using the hydrogen titanate nanowire and $\mathrm{LiOH} \cdot \mathrm{H}_{2} \mathrm{O}$ as starting materials with a hydrothermal method. The final LTO compound was synthesized at $700{ }^{\circ} \mathrm{C}$ for $6 \mathrm{~h}$ using a solid-state method. As a result of manufacturing the hybrid super capacitor using LTO synthesized at $180{ }^{\circ} \mathrm{C}$ for $36 \mathrm{~h}$ with the hydrothermal method, a capacity of $198 \mathrm{~mA} \cdot \mathrm{h} / \mathrm{g}$ has been achieved compared to a theoretical capacity of $172 \mathrm{~mA} \cdot \mathrm{h} / \mathrm{g}$ of existing LTO, and thus, the capacity has been increased by about $13 \%$. Further, such excellent cycle performance has ensured its possibility as a high-capacity capacitor.
\end{abstract}

Keywords: LTO $\left(\mathrm{Li}_{4} \mathrm{Ti}_{5} \mathrm{O}_{12}\right)$; lithium titanate oxide; hydrogen titanate nanowire; hybrid super capacitor

\section{Introduction}

Super capacitor refers to a promising energy storage technology that can be employed in various fields of applications for stabilizing the quality of portable small electronic device, hybrid electric vehicle (HEV), solar cell, wind power storage, smart grid, etc., and also enhancing the validity thereof. In particular, market expectation on energy storage devices and energy efficiency is currently increasing, and thus, the use of super capacitor is also increasing together with chemical cell. Currently, research on sodium-sulfur

\footnotetext{
* Corresponding author.

E-mail: yoonjungrag@samwha.com
}

$(\mathrm{NaS})$ battery and redox-flow battery as electrical energy storage devices is ongoing. In addition, research on the super capacitor having high output characteristics and lithium ion battery having high capacity characteristics is actively conducted [1-3]. Super capacitor can be classified into electric double layer capacitor (EDLC) having polar symmetry and hybrid super capacitor having polar asymmetry. Recently, the demand for hybrid super capacitor is rapidly increasing as high capacity and smallness are required. The hybrid super capacitor refers to a system of which charge and discharge mechanisms vary based on anode and cathode, and simultaneously has two advantages: the high output of EDLC and the high capacity of the secondary battery. Because the material of the anode and the material of the cathode differ, the used material significantly affects the characteristic 
value of a product. The anode generally uses an active material such as active carbon, etc., and the cathode uses graphite, $\mathrm{Li}_{4} \mathrm{Ti}_{5} \mathrm{O}_{12}$ (LTO), etc., as a cathode material. In the case of graphite, due to the formation of a solid electrolyte interface (SEI) layer, which acts as irreversible reaction in a low potential in the case of initial charge/discharge, the stability is decreased and the capacity and output are also degraded. Accordingly, the application of graphite is very limited. On the other hand, in the case of LTO, a report says that it configures the spinel structure, and thus is very stable due to a "zero-strain" characteristic that the volume expansion barely occurs in the case of charge/discharge, and also shows stable operational voltage of about $1.55 \mathrm{~V}$ compared to Li [2-5]. The solid phase method is generally used for LTO synthesis, and LTO has a size of about $100 \mathrm{~nm}$ to $500 \mathrm{~nm}$ through preparation at about $700{ }^{\circ} \mathrm{C}$ to $1000{ }^{\circ} \mathrm{C}$ [3-5]. LTO greatly affects charge/discharge characteristics based on the size and shape of powders. In particular, there is a report that a contact area between an electrode and an electrolyte increases according to an increase in a specific surface area whereby $\mathrm{Li}^{+}$transport distance decreases, thereby leading to enhancing a $\mathrm{Li}$-intercalation characteristic [4]. Accordingly, this research has proceeded with the experiment to achieve further excellent reversibility and to increase a charge/discharge rate during an intercalation/de-intercalation process of $\mathrm{Li}^{+}$by synthesizing the three-dimensional (3D) nano structure, i.e., spinel LTO, through an ion-exchange process using a hydrogen titanate precursor and then increasing the specific surface area. Further, this research aimed to verify the effects that the hydrogen titanate nanowire, the crystalline structure of LTO and the particle size thereof may have with respect to the electrochemical characteristics.

\section{Experiment}

\subsection{Preparation of LTO}

The synthesis procedure of LTO powders is shown schematically in Fig. 1. Ultrasound synthesis was performed at $70{ }^{\circ} \mathrm{C}$ for $6 \mathrm{~h}$ by using, as starting materials, $\mathrm{TiO}_{2} 60 \mathrm{~nm}$ (Showa Denko, F2, Japan) and $\mathrm{NaOH}$ (Junsei, Japan), and milling was performed for $24 \mathrm{~h}$ by using ball milling as a mixture condition. The LTO compound was synthesized by placing $\mathrm{LiOH} \cdot \mathrm{H}_{2} \mathrm{O}$ (Junsei, F2, Japan) and hydrogen titanate nanowire into a hydrogen titanate precursor as starting materials, and stirring the mixture and then maintaining the mixture at $150{ }^{\circ} \mathrm{C}$ for $36 \mathrm{~h}$ and $180{ }^{\circ} \mathrm{C}$ for $36 \mathrm{~h}$, respectively. The LTO compound was finally synthesized by maintaining the mixture at $700{ }^{\circ} \mathrm{C}$ for $6 \mathrm{~h}$ under air atmosphere, at a heating rate of $5{ }^{\circ} \mathrm{C} / \mathrm{min}$ from room temperature in a box furnace. The phase structure of the powders was characterized using an X-ray diffractometer (XRD, RIGAKU, RAD-C). The morphology of the synthesized powders was examined via scanning electron microscopy (SEM, JEOL, M7500F).

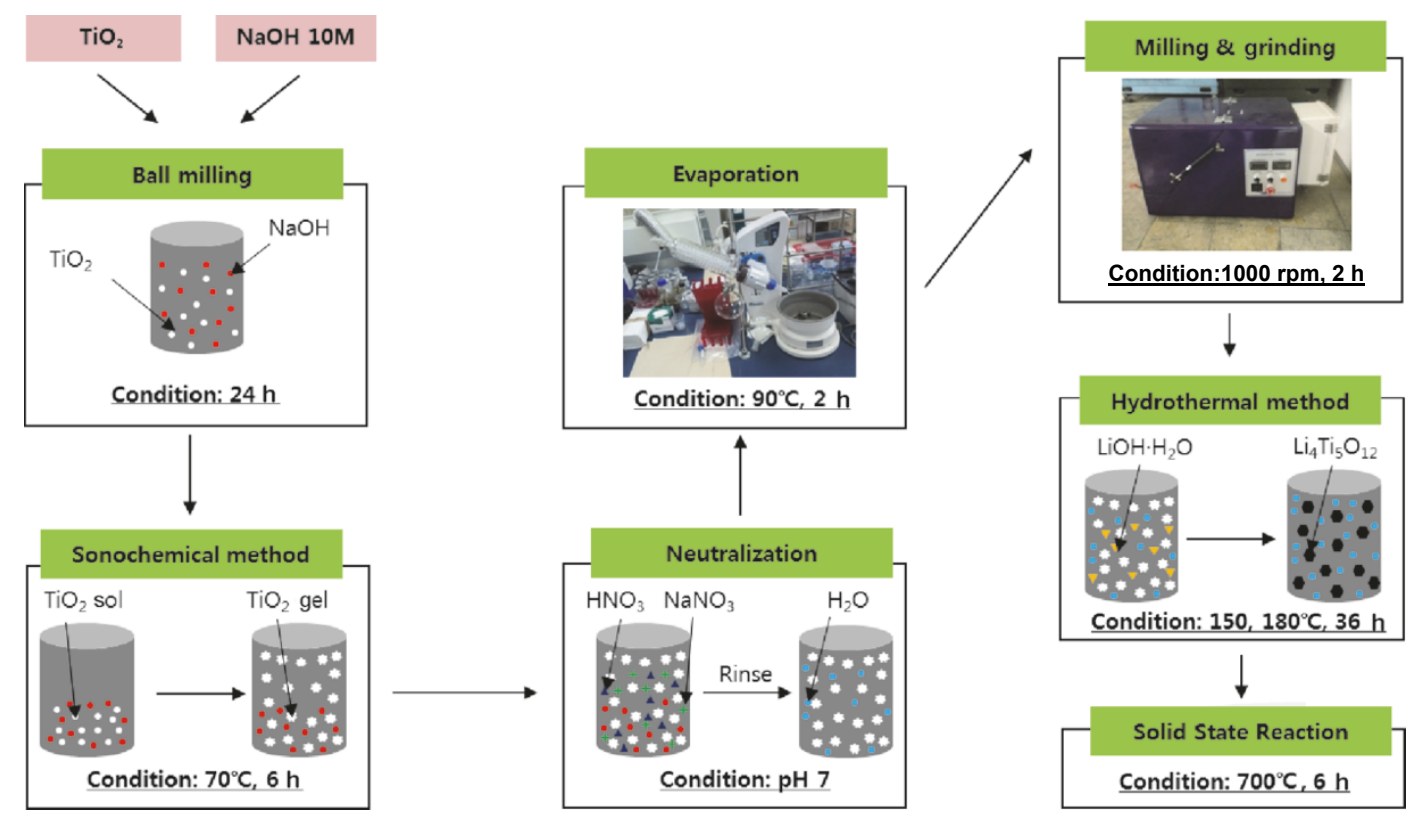

Fig. 1 Schematic for synthesis of spinel LTO via sonochemical and hydrothermal methods. 


\section{2 Preparation of hybrid super capacitor}

The negative electrode of the hybrid super capacitor was casted to have a thickness of $150 \mu \mathrm{m}$ by preparing a slurry in a solid loading condition of $39.61 \%$ using LTO (86.7\%), Super-P (3.89\%, Timcal), KS-6 (3.04\%, Timcal), PVdF (6.37\%, Arkema-HSV900) and N-Methyl-2-Pyrrolidone (NMP, Samchun Chemical). The positive electrode of the hybrid super capacitor was fabricated by using activated carbon (BET (Brunauer-Emmett-Teller) $=\sim 1700 \mathrm{~m}^{2} / \mathrm{g}$, ash content $<400 \mathrm{ppm}$, average particle size $=10 \mu \mathrm{m}) .1 .0 \mathrm{M}$ $\mathrm{LiPF}_{6} / \mathrm{ACN}$ electrolyte was applied as electrolyte. The hybrid super capacitor was prepared as coin-cell and non-woven fabric was used as separator. Electrochemical measurement was implemented using a CV (cyclic voltammetry)-meter at a room temperature. The charge/discharge experiment was implemented by setting cut-off voltage to be up to $0 \mathrm{~V}$ to $2.8 \mathrm{~V}$ as the measurement condition and setting a $\mathrm{C}$-rate to be within the range of $1 \mathrm{C}$ to $10 \mathrm{C}$. Cyclic characteristics were measured by setting the C-rate at $1 \mathrm{C}$ and cut-off voltage to be $0 \mathrm{~V}$ to $2.8 \mathrm{~V}$.

\section{Results and discussion}

Figure 2(a) shows the FE (field emission)-SEM image acquired through mixing hydrogen titanate nanotube and $\mathrm{LiOH} \cdot \mathrm{H}_{2} \mathrm{O}$ at the molar ratio of $5: 2$ and then stirring the mixture at room temperature for $2 \mathrm{~h}$, and hydrothermally synthesizing the obtained powders at $150{ }^{\circ} \mathrm{C}$ for $36 \mathrm{~h}$. As illustrated, it can be seen that particles in the nanowire form and particles in the cohered powder form were simultaneously synthesized. Further, it can be verified that the length of the nanowire is about $500 \mathrm{~nm}$. Figure 2(b) shows the FE-SEM image obtained through the hydrothermal synthesis at $180{ }^{\circ} \mathrm{C}$ for $36 \mathrm{~h}$. It can be known that the aspect ratio of the nanowire has increased by about two folds compared to the experiment implemented at $150{ }^{\circ} \mathrm{C}$. Further, it can be ascertained that the nanowire can be easily synthesized when the supply of sufficient heat energy is maintained [6-11]. Figure 2(c) shows the FE-SEM image obtained by finally synthesizing the LTO powders, synthesized at $150{ }^{\circ} \mathrm{C}$ for $36 \mathrm{~h}$ using the hydrothermal synthesis method, at $700{ }^{\circ} \mathrm{C}$ for $6 \mathrm{~h}$ in the box furnace. Compared to the FE-SEM image of Fig. 2(a), it can be seen from the FE-SEM image of Fig. 2(c) that the nanowire form has disappeared. When heat treatment is performed at high temperature such as $700{ }^{\circ} \mathrm{C}$, ion-exchange is in active progress, which is different from the heat treatment performed at low temperature such as $150{ }^{\circ} \mathrm{C}$. Accordingly, the nanowire structure is thought to have been completely collapsed due to removal of $\mathrm{Na}^{+}$ions that support the nanowire.

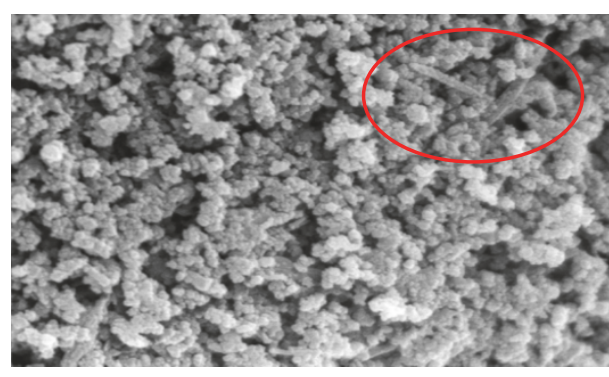

(a)

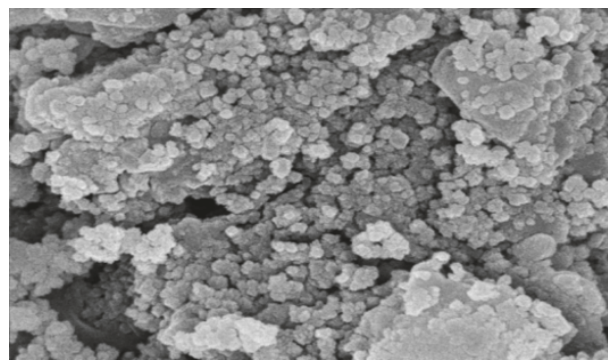

(c)

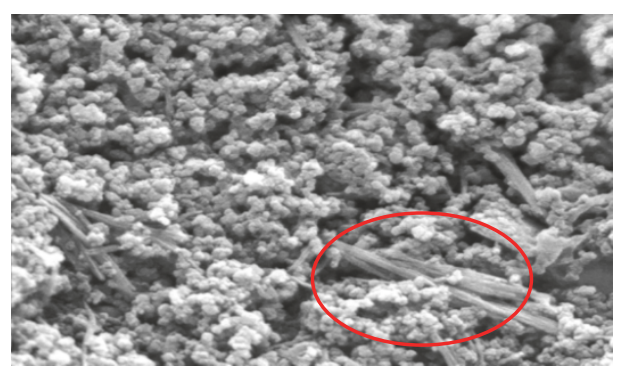

(b)

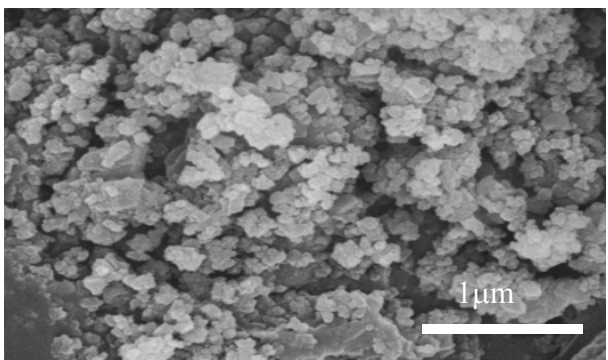

(d)

Fig. 2 FE-SEM images of LTO synthesized by hydrothermal method at (a) $150{ }^{\circ} \mathrm{C}, 36 \mathrm{~h}$ and (b) $180{ }^{\circ} \mathrm{C}, 36 \mathrm{~h}$; (c) and (d) LTO finally synthesized by solid-state reaction method at $700{ }^{\circ} \mathrm{C}, 6 \mathrm{~h}$. 
Figure 2(d) shows the FE-SEM image obtained by finally synthesizing the LTO powders, synthesized at $180{ }^{\circ} \mathrm{C}$ for $36 \mathrm{~h}$ using the hydrothermal synthesis method, at $700{ }^{\circ} \mathrm{C}$ for $6 \mathrm{~h}$ in the box furnace. Similarly, it can be seen that the nanowire form has disappeared. Figure 3 shows the result of analyzing the XRD experiment. In the cases of the powders synthesized at $150{ }^{\circ} \mathrm{C}$ and $180{ }^{\circ} \mathrm{C}$, it can be ascertained that the crystalline surface, which is the main peak (111) of LTO, is strongly observed around about $18.12^{\circ}$ as a result of comparing and analyzing the position of each peak with respect to the synthesized powders using JCPDS card. Further, it can be verified that the peak of sodium nitrate $\left(\mathrm{NaNO}_{3}\right)$, which is the product of sodium hydroxide $(\mathrm{NaOH})$ and nitric acid $\left(\mathrm{HNO}_{3}\right)$, is observed around about $28.88^{\circ}$. That $\mathrm{Na}^{+}$ions and $\mathrm{NO}_{3}{ }^{-}$ ions are not completely removed during synthesizing the hydrogen titanate nanowire is considered as the reason that $\mathrm{NaNO}_{3}$ is produced. Meanwhile, electrochemical characteristics were measured in order to find out the intercalation/de-intercalation process of $\mathrm{Li}^{+}$as cathode of the hybrid super capacitor. Figure 4 shows the result of cyclic voltammetry. In general, cyclic voltammetry (CV) is known as a tool suitable to indicate the difference between non-faradaic reaction and faradaic reaction. Through this, a comparison and analysis on the power density and the energy density of the super capacity can be performed [7]. In this experiment, a section was set to be from $0 \mathrm{~V}$ to $2.8 \mathrm{~V}$, and measurement was implemented by adjusting a sweep-rate to be from $20 \mathrm{mV} / \mathrm{S}$ to $100 \mathrm{mV} / \mathrm{S}$. It can be known from Fig. 4(a) that the reduction peak is

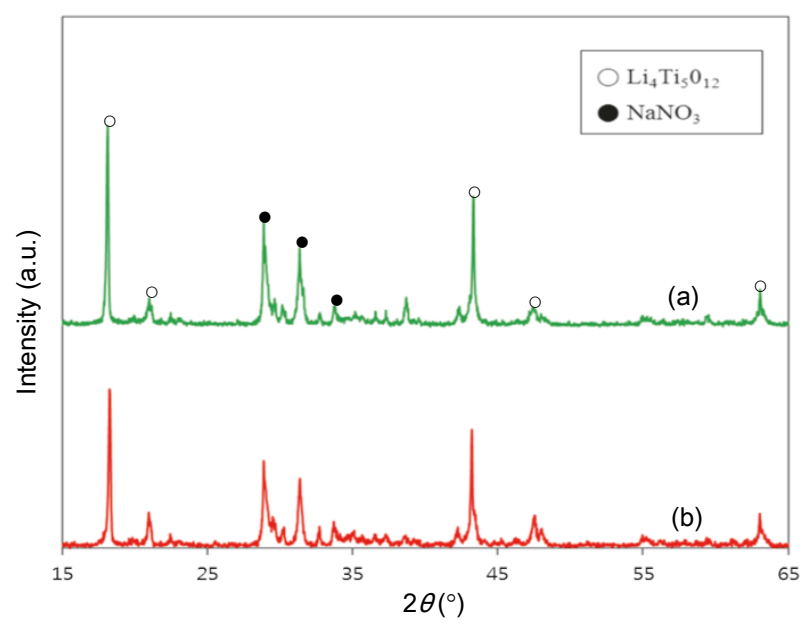

Fig. 3 XRD patterns of LTO synthesized by hydrothermal method at (a) $150{ }^{\circ} \mathrm{C}, 36 \mathrm{~h}$ and (b) $180{ }^{\circ} \mathrm{C}, 36 \mathrm{~h}$.
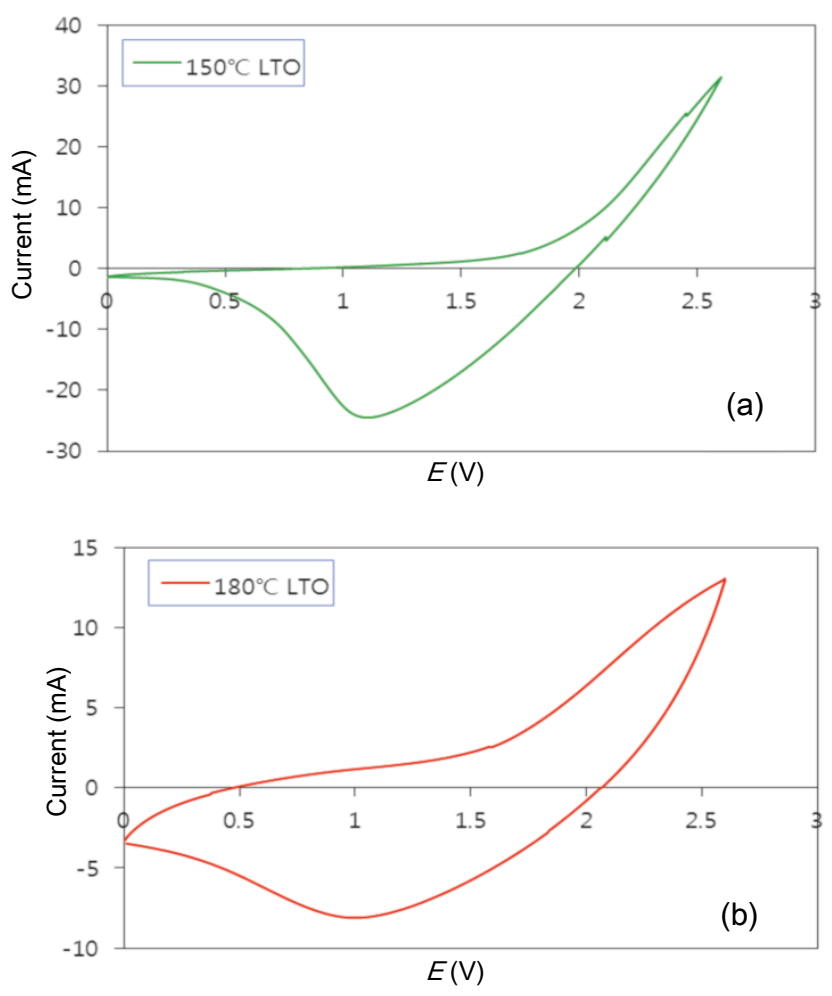

Fig. $4 \mathrm{CV}$ results of LTO synthesized by hydrothermal method at (a) $150{ }^{\circ} \mathrm{C}$ and (b) $180{ }^{\circ} \mathrm{C}$.

observed at about $1.4 \mathrm{~V}$, and the oxidation peak is observed at $1.8 \mathrm{~V}$. It can be known from Fig. 4(b) that the idealistic rectangular $\mathrm{CV}$ curve is observed compared to Fig. 4(a). Further, it can be known that the reduction peak is observed at about $1.4 \mathrm{~V}$ and the oxidation peak is observed at $1.7 \mathrm{~V}$, and thus, the oxidation-reduction is verified. In general, it is known that the spinel LTO discharge peak $\left(\mathrm{Li}^{+}\right.$intercalation) occurs at $1.5 \mathrm{~V}$ and the charge peak $\left(\mathrm{Li}^{+}\right.$ de-intercalation) occurs at $1.7 \mathrm{~V} \quad[8-10]$. The mechanisms of the hybrid super capacitor are described in the following equations:

$$
\begin{gathered}
\mathrm{AC}+\mathrm{PF}_{6}^{-} \leftrightarrow \mathrm{AC}^{+} \cdot \mathrm{PF}_{6}^{-}+\mathrm{e}^{-} \text {(cathode) } \\
\mathrm{Li}_{4} \mathrm{Ti}_{5} \mathrm{O}_{12}+3 \mathrm{Li}^{+}+3 \mathrm{e}^{-} \leftrightarrow \mathrm{Li}_{7} \mathrm{Ti}_{5} \mathrm{O}_{12} \text { (anode) }
\end{gathered}
$$

It can be verified from $3 \mathrm{Li}^{+}+3 \mathrm{e}^{-} \leftrightarrow \mathrm{Li}_{4} \mathrm{Ti}_{5} \mathrm{O}_{12}$, which is an anode reaction equation, that de-intercalation of $\mathrm{Li}$ is performed and the oxidation peak is observed at $1.7 \mathrm{~V}$. Accordingly, it is possible to verify the shape of the capacitor. Electrochemical impedance spectroscopy (EIS) is an analysis method of applying an alternating current (AC) potential to an electrochemical device and system and measuring impedance corresponding to complex resistance from the $\mathrm{AC}$ that is detected when the AC potential is applied $[9,10]$. In general, EIS is exhibited as a 
Nyguist plot by employing a real number portion $\left(Z_{\mathrm{re}}\right)$ of the impedance as $X$ axis and an imaginary number portion $\left(Z_{\text {im }}\right)$ of the impedance as $Y$ axis. As an analysis result using the above method, it can be known from Fig. 5(a) that an initial semicircle occurs. The initial semicircle is thought to occur due to resistance that occurs around an interface of an electrode during a charge process. In addition, it can be verified that a linear curve that gradually increases at a gradient of 45 degrees as the frequency decreases around about $100 \Omega$ is obtained and thus, the typical capacitor shape appears [12,13]. It can be ascertained from Fig. 5(b) that the internal resistance decreases compared to Fig. 5(a). Accordingly, collectively referring to the aforementioned results, compared to the hybrid super capacitor prepared at $150{ }^{\circ} \mathrm{C}$, the hybrid super capacitor prepared at $180{ }^{\circ} \mathrm{C}$ using the hydrothermal synthesis method exhibits that the diffusion distance of $\mathrm{Li}^{+}$ decreases and the diffusion rate is enhanced due to the increased nanowire, and low electrochemical reaction resistance is generated during a discharge process due to a high non-specific area [13-15]. Figure 6 is a graph showing the discharge capacity according to C-rate. It can be seen that the capacity decreases according to an increase in the current density, and a relatively small
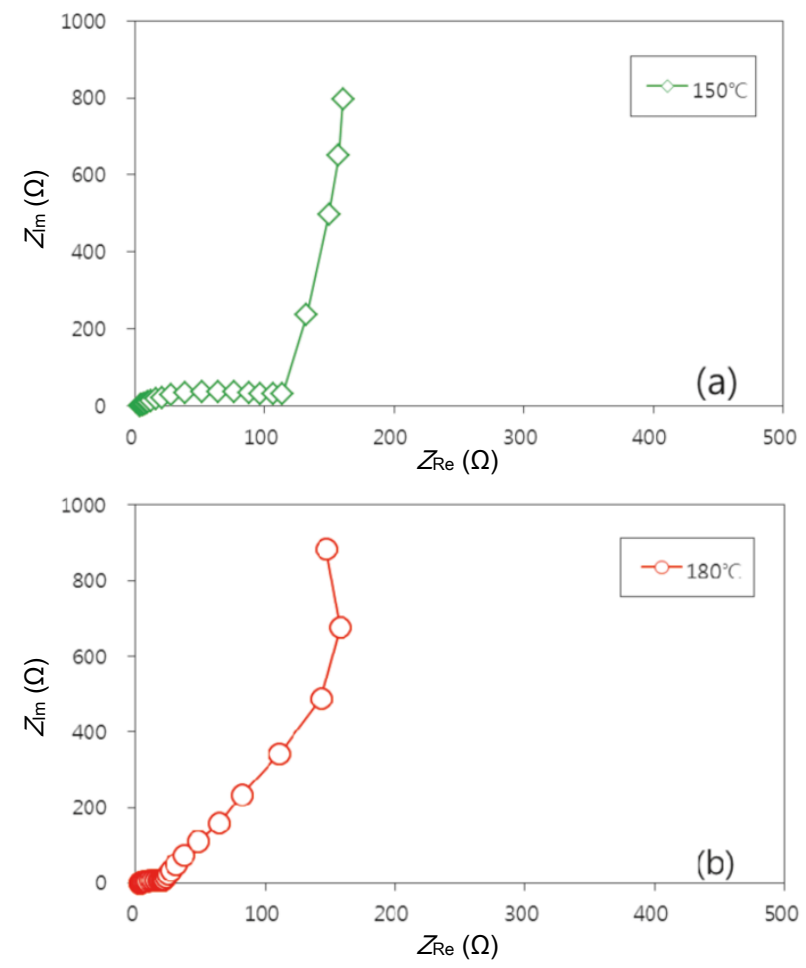

Fig. 5 Nyquist plots of LTO synthesized by hydrothermal method at (a) $150{ }^{\circ} \mathrm{C}$ and (b) $180{ }^{\circ} \mathrm{C}$. capacity loss is observed in $180{ }^{\circ} \mathrm{C}$ compared to $150{ }^{\circ} \mathrm{C}$ when the measurement is implemented at $10 \mathrm{C}$. Further, it can be ascertained that the capacity decreases by about $90 \%$ compared to the capacity measured at $1 \mathrm{C}$. Figure 7 is a graph showing a change rate of capacity according to the number of cycles. As the cycle number proceeds, the decrease rate of capacity is observed. Also, it can be verified that the capacity measured at 30 cycles has decreased by (a) $29.19 \%$ and (b) $23.75 \%$ compared to the initial capacity, respectively. Accordingly, compared to the hybrid super capacitor prepared at $150{ }^{\circ} \mathrm{C}$, it can be ascertained that the hybrid super capacitor prepared at $180{ }^{\circ} \mathrm{C}$ using the hydrothermal synthesis method has excellent charge/discharge retention and cycle characteristics [15-17].

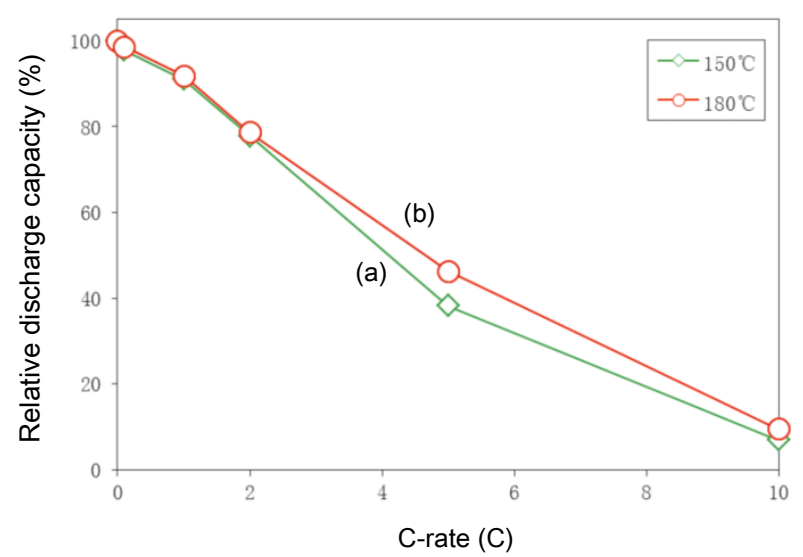

Fig. 6 Relative discharge capacity with respect to C-rate of LTO synthesized by hydrothermal method at (a) $150{ }^{\circ} \mathrm{C}$ and (b) $180{ }^{\circ} \mathrm{C}$.

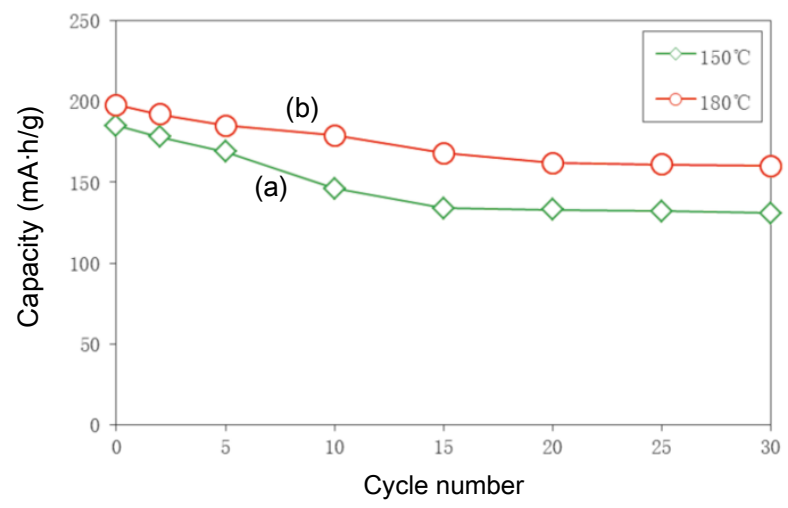

Fig. 7 Discharge capacity with respect to cycle number of LTO synthesized by hydrothermal method at (a) $150{ }^{\circ} \mathrm{C}$ and (b) $180{ }^{\circ} \mathrm{C}$. 


\section{Conclusions}

This research observed the optical characteristics and structure of LTO according to growth temperature in the hydrothermal synthesis method using $\mathrm{TiO}_{2}$ having the hydrogen titanate nanowire form. As a result of preparing the hybrid super capacitor using the synthesized LTO, it can be known that the product synthesized at $180{ }^{\circ} \mathrm{C}$ using the hydrothermal synthesis method exhibits the idealistic rectangular CV curve compared to the product prepared at $150{ }^{\circ} \mathrm{C}$. As the analysis result using the Nyguist plot method, it can be verified that the linear curve that gradually increases at a gradient of 45 degrees as the frequency decreases around about $100 \Omega$ is obtained and thus the typical capacitor shape appears. Further, as a result of measuring the discharge capacity according to the C-rate, it can be known that the capacity suddenly decreases according to an increase in the current density. It can be ascertained that the product synthesized at $180{ }^{\circ} \mathrm{C}$ has excellent charge/discharge retention and cycle characteristics as the cycle number proceeds.

Open Access: This article is distributed under the terms of the Creative Commons Attribution Noncommercial License which permits any noncommercial use, distribution, and reproduction in any medium, provided the original author(s) and source are credited.

\section{References}

[1] Lee B-G, Yoon J-R. Preparation and characteristics of $\mathrm{Li}_{4} \mathrm{Ti}_{5} \mathrm{O}_{12}$ anode material for hybrid supercapacitor. J Electr Eng Technol 2012, 7: 207-211.

[2] Frackowiak E, Béguin F. Carbon materials for the electrochemical storage of energy in capacitors. Carbon 2001, 39: 937-950.

[3] Zaghib K, Armand M, Gauthier M. Electrochemistry of anodes in solid-state $\mathrm{Li}$-ion polymer batteries. J Electrochem Soc 1998, 145: 3135-3140.

[4] Ferg E, Gummow RJ, de Kock A, et al. Spinel anodes for lithium-ion batteries. $J$ Electrochem Soc 1994, 141: L147-L150.
[5] Kim J, Cho J. Spinel $\mathrm{Li}_{4} \mathrm{Ti}_{5} \mathrm{O}_{12}$ nanowires for high-rate Li-ion intercalation electrode. Electrochem Solid-State Lett 2007, 10: A81-A84.

[6] Xing W, Qiao SZ, Ding RG, et al. Superior electric double layer capacitors using ordered mesoporous carbons. Carbon 2006, 44: 216-224.

[7] Amatucci GG, Badway F, Du Pasquier A, et al. An asymmetric hybrid nonaqueous energy storage cell. J Electrochem Soc 2001, 148: A930-A939.

[8] Colbow KM, Dahn JR, Haering RR. Structure and electrochemistry of the spinel oxides $\mathrm{LiTi}_{2} \mathrm{O}_{4}$ and $\mathrm{Li}_{4 / 3} \mathrm{Ti}_{5 / 3} \mathrm{O}_{4}$. J Power Sources 1989, 26: 397-402.

[9] Ohzuku T, Ueda A, Yamamoto N. Zero-strain insertion material of $\mathrm{Li}_{[}\left[\mathrm{Li}_{1 / 3} \mathrm{Ti}_{5 / 3}\right] \mathrm{O}_{4}$ for rechargeable lithium cells. $J$ Electrochem Soc 1995, 142: 1431-1435.

[10] Yuan T, Cai R, Ran R, et al. A mechanisim study of synthesis of $\mathrm{Li}_{4} \mathrm{Ti}_{5} \mathrm{O}_{12}$ from $\mathrm{TiO}_{2}$ anatase. $J$ Alloys Compd 2010, 505: 367-373.

[11] Bavykin DV, Friedrich JM, Walsh FC. Protonated titanates and $\mathrm{TiO}_{2}$ nanostructured materials: Synthesis, properties, and applications. Adv Mater 2006, 18: 2807-2824.

[12] Li J, Tang Z, Zhang Z. Controllable formation and electrochemical properties of one-dimensional nanostructured spinel $\mathrm{Li}_{4} \mathrm{Ti}_{5} \mathrm{O}_{12}$. Electrochem Commun 2005, 7: 894-899.

[13] Sun X, Li Y. Synthesis and characterization of ion exchangeable titanate nanotubes. Chem-Eur J 2003, 9: 2229-2238.

[14] $\mathrm{Du}$ Pasquier A, Laforgue A, Simon P. $\mathrm{Li}_{4} \mathrm{Ti}_{5} \mathrm{O}_{12} /$ poly(methyl)thiophene asymmetric hybrid electrochemical device. J Power Sources 2004, 125: 95-102.

[15] Ju SH, Kang YC. Effects of preparation conditions on the electrochemical and morphological characteristics of $\mathrm{Li}_{4} \mathrm{Ti}_{5} \mathrm{O}_{12}$ powderss prepared by spray pyrolyis. J Power Sources 2009, 189: 185-190.

[16] Stoller MD, Murali S, Quarles N, et al. Activated graphene as a cathode material for Li-ion hybrid supercapacitors. Phys Chem Chem Phys 2012, 14: 3388-3391.

[17] Ni J, Yang L, Wang H, et al. A high-performance hybrid supercapacitor with $\mathrm{Li}_{4} \mathrm{Ti}_{5} \mathrm{O}_{12}-\mathrm{C}$ nano-composite prepared by in situ and ex situ carbon modification. J Solid State Electr 2012, 16: 2791-2796. 